\title{
Experimental Approach to Soil Research Conforming to Compressed Brick Production for Housing Construction in Chad
}

\author{
Bozabe Renonet Karka ${ }^{1}$. Bassa Bruno ${ }^{2}$ \\ ${ }^{1}$ Department of Civil Engineering, National High School of Publics Works (NHSPW), University of N'Djamena, N'Djamena, Chad. \\ ${ }^{2}$ Faculty of Exact and Applied Sciences (FEAS), University of N'Djamena, N'Djamena, Chad.
}

\begin{abstract}
The study presents an appropriate soil recognition process for the production of reliable compressed earth bricks (CEB) in Pala, Mayo-Kebbi West. Samples were collected from the quarries of Goub-goub, Madagascar, Yatilim, Sara and subjected to on-site and laboratory identification tests. After analysis and interpretations of the results, it emerges that the red grainy soil made up of a silty earth taken from the site of Sara is the ideal soil for the earth construction. This soil makes it possible to obtain a good compaction because it is naturally well graded $\left(C_{u}=14.40\right.$ and $\left.C_{c}=1.37\right)$ and it is little plastic $\left(I_{P}=13.60\right)$ so little sensitive to bad weather. Soil of hard consistency $\left(\mathrm{I}_{\mathrm{C}}=2.68\right)$, it is difficult to scratch with the thumbnail. Also, by stabilizing it with $9 \%$ of the rice bran by simple compression in a press of 5 to $10 \mathrm{kN}$, its compression resistance (CR) after cure of 28 days approaches $11.80 \mathrm{MPa}$, value between $5 \mathrm{MPa}$ and $20 \mathrm{MPa}$; an interval required by the International Center for Earth Construction, CRA terre. To be eligible, soil samples from the other three quarries must undergo granular changes by adding missing grain sizes or by reducing/eliminating excess grain sizes so that these soils are reduced to well graded and little plastic. And if there are cracks and/or volumetric changes on bricks made with these types of soils, the present study reveals that a reasonable proportion of mineral, plant or animal binder must be added. Finally, whether it is perfect for construction or not, the earth remains the most desired material by users because, apart from its countless technical, ecological and economic qualities, it also integrates our cultural heritage.

(C) 2022 JMSSE - INSCIENCEIN. All rights reserved
\end{abstract}

\section{Introduction}

Inaccessibility to decent housing is a major problem for the Chadian people. Indeed, owning a suitable home is a luxury that only a small part of Chadians benefits from. That is why we must use local materials and appropriate construction techniques that promote economic development and well-being by favouring affordable and equitable access for all Chadians. Thus, earthen construction appears to be a reliable and suitable technique because it has been an integral part of our cultural heritage for centuries. This construction technique, with its many ecological and economic advantages, is unfortunately now being abandoned in favour of modern constructions, types of architecture that do not seem to fit our environmental and social contexts [1].

Considered the cheapest, universal and recyclable material, the earth has been used in construction for millennia, making the construction of earth the most widespread habitat in the world in general and in Chad in particular. Unfortunately, this old technique with many advantages tends to disappear in the country of Toumaï (Chad) in favour of concrete construction, a type of construction that is not very economical and less adapted to the arid and hot climate [2].

Through this theme, we want to promote the integration of traditional housing and convince the Chadian population that earthen construction, whether raw, cooked or stabilized, is the real engine of infrastructural development [3]. Gradually bring each Chadian to understand that the earth as a local material, if well studied and analyzed, offers an unprecedented comfort to its users and can have the same mechanical characteristics as other materials such as concrete. In order to achieve this objective, and given the diversity of the land, two fundamental questions must be asked: 1. what type of land is appropriate for the construction of a structure? 2. what are the appropriate techniques for performing an earthwork?

To better understand the first question and given that the very principle of earthen construction, according to ClaireAnne de Chazelles (2015) is adaptation to the environment, this work will address the need to study and analyse land materials adapted to the local conditions of the city of Pala, the capital of the province of Mayo-Kebbi West in Chad [4]. Field and 'in-situ' tests include visual examination, touchtesting, hand washing and cigar testing, and laboratory tests such as dry sieve particle size analysis, Atterberg limits, and compression resistance (CR) testing. The results of investigations from samples from different quarries will be used not only to select the type of production land for bricks stabilized by simple compression but also, to eradicate the ignorance by most of the actors of construction of the material earth, of its constraints and qualities which is undoubtedly the main cause of disorders and sinister in the habitat currently in Chad. From this finding and in order to eradicate these disorders and reduce energy consumption (massive use of charcoal) leading to the increase in greenhouse gases, the information that will come from this modest research work will enable the authorities to launch a call for national awareness on the valorisation of the earth material.

\section{Experimental \\ Materials}

Pala is the chief town of the Mayo-Kebbi West region in Chad, with geographical coordinate's $9.364^{\circ}$ latitude, $14.905^{\circ}$ longitude and $433 \mathrm{~m}$ altitude (Figure 1 ). The town 
of Pala and its surrounding villages are full of huge earth building materials of acceptable properties which are: clay, laterite, limestone, rocks, etc. [5]. Briefly, we define each type of material in the presence and then, in-situ field tests and laboratory tests will be carried out on soil samples taken from the quarries of the sites of Goub-goub, Madagascar, Yatilim and Sara (Figure 2). The soil considered suitable will therefore be simply compressed in a local press after adding a stabilizer, the rice bran in order especially to limit cracks and dimensional drifts to drying.
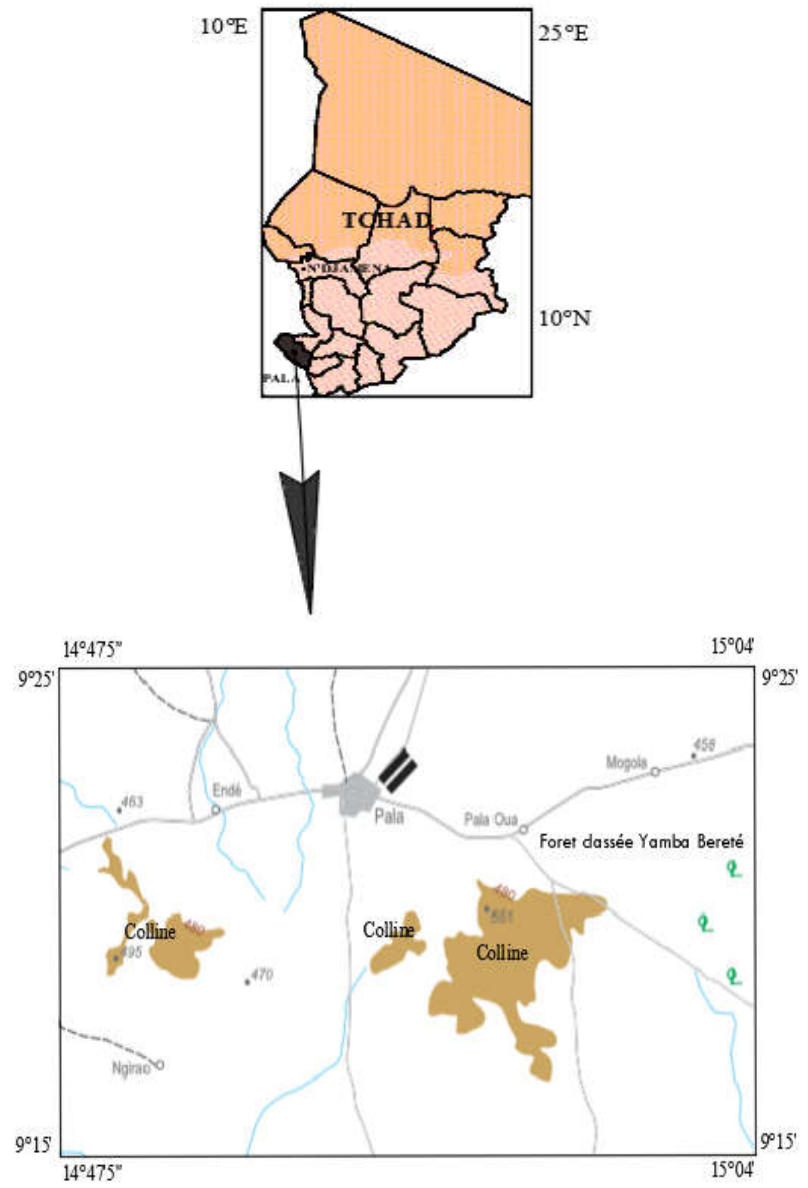

Figure 1: Map of Chad and Location of the study area
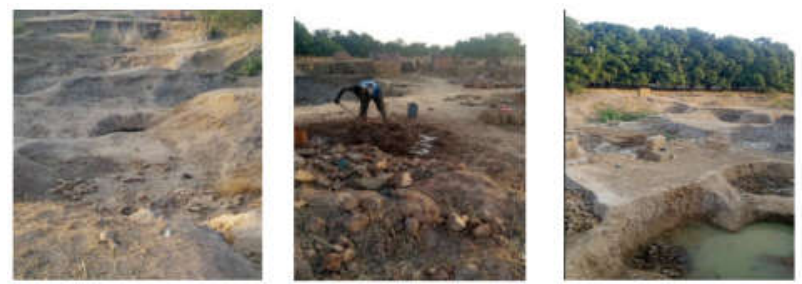

Figure 2: Examples of brick quarries in and around Pala

\section{Constitution of the soil of the locality}

Soils are mineral but also organic aggregates that can break down into larger or smaller elements without requiring considerable effort. The mineral fraction results from the alteration of the parent rock. Carbonization, oxidation and leaching are the processes of transformation of the organic fraction. There are two types of soil: residual soil, formed on-site by alteration and without transport and transported soil. Both are made up of several categories of grain (Table 1) divided into several overlapping horizontal layers [6]. These are called horizons. According to Anger and Fontaine (2009), from top to bottom, the A-horizon is darker than the lower layers, corresponds to topsoil (superficial) and therefore cannot be used in construction. Horizon B is the earth used in construction as it contains less organic matter. In the end, the horizon $\mathrm{C}$ consists essentially of the decaying rock, located halfway between the mother rock and the earth. At the bottom of the latter, we meet the mother rock. Note that a soil sample consists of three phases: gas phase, liquid phase and solid phase [7].

\begin{tabular}{cc}
\multicolumn{2}{c}{ Table 1: Size classes of a soil in general } \\
\hline Rock blocks & $\mathrm{D}>200 \mathrm{~mm}$ \\
Callous & $20 \mathrm{~mm}<\mathrm{D}<200 \mathrm{~mm}$ \\
Gravel & $2 \mathrm{~mm}<\mathrm{D}<20 \mathrm{~mm}$ \\
Coarse sands & $0,2 \mathrm{~mm}<\mathrm{D}<2 \mathrm{~mm}$ \\
Fine sands & $20 \mu \mathrm{m}<\mathrm{D}<0,2 \mathrm{~mm}$ \\
Silts & $2 \mu \mathrm{m}<\mathrm{D}<20 \mu \mathrm{m}$ \\
Clays & $\mathrm{D}<2 \mu \mathrm{m}$ \\
\hline
\end{tabular}

The clays

Clays are fine-grained sedimentary rocks, less than $2 \mu \mathrm{m}$ in size, containing at least $50 \%$ alumina silicate. They absorb water and form an impermeable paste commonly known as clay, coloured with iron oxides in ochre, red, etc.

Clays can be bulky, especially those of the montmorillonite family when they absorb water and, on the contrary, decrease in volume under the effect of drought, going as far as cracking on the surface and even on a depth of $2 \mathrm{~m}$ to 4 $\mathrm{m}$. Moreover, under the effect of a charge, a portion of the water absorbed between the clay grains is removed, which may cause a sensitive settling of the soil [8].

Clays are generally an acceptable to poor base when covered by other land layers [9]. On the other hand, they are dangerous when they outcrop at ground level because of their instability, resulting in volume variations and creep in sloping terrain [10]. Other types of fine-grained sediments contain clays such as marls, loess (claylimestone rock composed of very fine clay, limestone and quartz particles), etc.

\section{The laterite}

Laterite as an ore is the red soils that are widespread in tropical and subtropical regions. These heavily altered soils found at shallow depths are rich in iron oxides $\left(\mathrm{Fe}_{2} \mathrm{O}_{3}\right)$ and alumina $\left(\mathrm{Al}_{2} \mathrm{O}_{3}\right)$ [11]. Their consistency goes from gravel to rock, which makes their great feature of utility in construction (buildings, roads, etc.) for tropical countries.

Laterite has several morphological, chemical and mineralogical characteristics. There are two types of laterite morphologically:

1.A loose laterite used both in road construction and in the construction of houses made of compressed earth blocks (this is the case of our sample);

2.An indurate laterite used specifically for the construction of houses in blocks of cut earth.

\section{The limestone}

Limestone is a sedimentary rock formed by calcium carbonate. It is of organic origin, this is the case of chalk and shelled limestone, either of chemical origin, like calcite or Eolithic limestone. Limestone may contain cavities of natural origin, karsts formed by dissolution of rock, but also in the subsoil. Chalk is a friable limestone, porous and thirsty for water. Calcined at $800^{\circ} \mathrm{C}$, it gives quicklime [12]. Limestone is often a good foundation level in the absence of underground mining. Limestones may be adapted or unusable for the various uses for which they are intended. They can be used as sculpture materials, as 
building rock used in construction and as a constituent of cement.

A geological survey conducted in the province of MayoKebbi West since 1948, supplemented by a survey of the marl deposits of Pala-Erdé in 1953, highlighted a reserve of more than 8 million tons of limestone and marl. This study is part of the establishment of the current cement plant in Baoaré. Table 2 gives an estimate of the quantity of these reserves.

Besides limestone and marl, iron ore, gypsum and red clay are found in the Baoaré region. Thanks to the drilling carried out, the following results can be found in the same report:

1.Limestone: 2,756,068 tonnes;

2.Marl: 484,408 tonnes;

3. Clays: $1,085,936$ tonnes.

Table 2: Estimates of local limestone reserves

\begin{tabular}{ccc}
\hline Location & Size (HA) & $\begin{array}{c}\text { Quantity of reserves } \\
\text { (million tonnes) }\end{array}$ \\
Baoaré & 20 & 2.8 \\
Tagobo Foulbé & 40 & 2 \\
Tagobo Foulbé Est & 200 & 10 \\
Louga & 65 & 2.5 \\
Poukra & 200 & 9.8 \\
Total & & 27.1 \\
\hline
\end{tabular}

The rock stones

Man has always used the natural materials of the subsoil, the rocks for his constructions. Any material constituting the Earth's crust is by definition called rock. A quarry is a place from which building materials are extracted: stone, sand or different non-metallic or carboniferous minerals (as opposed to mines)

The rocks have a wide variety of features and properties. We find:

1.Consistent and hard rock's such as granite or marble;

2. Brittle rocks such as chalk or talc;

3. Plastic and modelable rocks mixed with water like clay;

4.Impermeable and permeable rocks.

Depending on their origins, they are classified into three groups: magmatic or eruptive rocks (granite, basalt, etc.), sedimentary rocks (clay, sand, gravel, limestone for example) and metamorphic rocks (schist, marble, etc.).

\section{Methods}

In-situ Field Identification Testing [13-16]

Among the different field identification tests, we only select four: the visual examination, the touch test, the hand washing test and the cigar test. After these tests, we will choose the ideal type of soil from the samples taken from the four quarries mentioned above for the production of compressed bricks.

\section{Visual examination and touch test}

Both tests make it possible to know the size of the soil by examining with the naked eye and touch the soil being studied.Visual examination identifies gravel and coarse sand while grains with a diameter less than $80 \mu \mathrm{m}$ will be associated with the fine fraction to be identified on touch.

For the touch test, a small amount of soil is removed between the fingers and the palm of the hand (Figure 3 ). During the touch test, three cases arise: 1 . if a certain roughness is felt on the touch and if there is no cohesion between the grains even after humidification of the sample, the soil will be designated as sandy; 2 . if there is a low roughness and after humidification the sample becomes medium plastic, the soil will be silky. 3. If the soil is crushed in the dry state and becomes plastic and sticky after humidification, the soil shall be called clay.
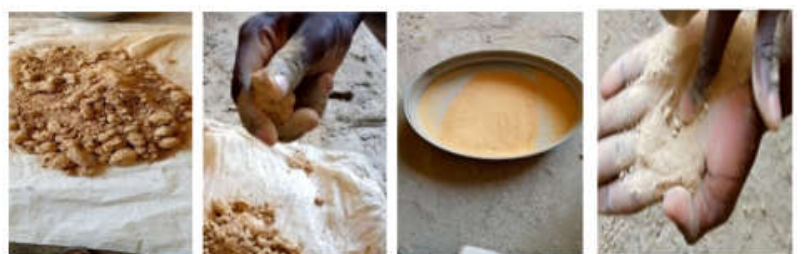

Figure 3: Visual Examination and Touch Test

\section{Hand Washing Tests}

The hand-washing test will confirm whether the soil is clay, silty or sandy. To do this, lightly wet the soil and coat your hands with it (Figure 4). Then try to clean your hands. Three cases arise: 1 . if they rinse easily, it is because it is sand. 2. if the hands are not too difficult to wash and if the appearance of the earth is powdery, it is silky. 3. if, on the other hand, the hands are difficult to wash and you have a soapy sensation when washing, it is clay.
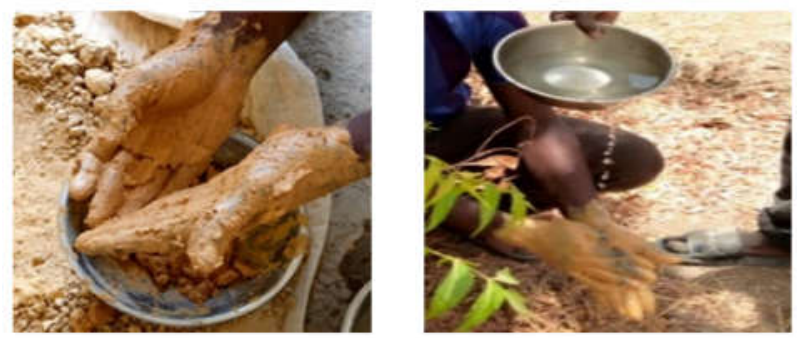

Figure 4: Hand Washing Test

Test du cigar

With the cigar test, we can determine the cohesion of the soil. To do this, the soil is passed through a $5 \mathrm{~mm}$ sieve to remove all particles larger than $5 \mathrm{~mm}$ in diameter and the amount of water required to obtain a plastic soil is added. The mixture is left to stand for one hour for the clay to react with the water and then a $3 \mathrm{~cm}$ diameter and $20 \mathrm{~cm}$ long pudding is made using the palm of the hands. It is then gently pushed into the void (Figure 5). The cigar will break under its own weight. The fracture length is then measured. Three cases arise: 1.If the broken cigar tip measures less than $5 \mathrm{~cm}$, it is because the earth is sandy; 2 . If the cigar breaks after $15 \mathrm{~cm}$, the earth will be called clay; 3 . If the fallen tip measures between $5 \mathrm{~cm}$ and $15 \mathrm{~cm}$, the land is considered suitable for earth construction techniques. This test must be repeated three times to ensure the accuracy of the results obtained.
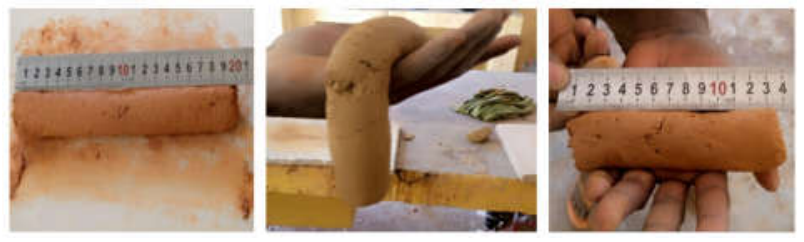

Figure 5: Cigar Test

\section{Laboratory Identification Testing}

1.The various standardized laboratory tests are:

2.Water content by weight (NF P 94 - 050);

3.Dry sieving particle size analysis (NFP 94 - 056, March 1996);

4.Atterberg boundaries (NF P 94 - 051 of March 1993). 
Stabilization techniques [17-19]

According to Gernot Minke, 2009, the stabilization of raw earth aims to improve its mechanical properties and durability for better resistance to mechanical and climatic stresses. Stabilization processes have a varied connotation in the literature. According to Danso et al, 2015, there are three stabilization methods: 1. Fibber-based reinforcement; 2. Binder-based reinforcement; and 3 . Combination reinforcement. However, it is advisable to choose the one that is appropriate in relation to the type of earth construction used and the variety of land used. The properties of the earth that can be changed are texture and structure. Since the land in its natural state already has many interesting properties, the use of stabilizers is not always necessary. But when they are needed, they must be used carefully, because they are relatively expensive and require numerous studies to meet the needs that are lacking.

\section{Stabilization by mineral addition}

This method involves controlling the removal and swelling in order to obtain a better distribution of the porosity. It also helps to improve the cohesion between the earth's particles. Thus, for a soil too rich in clay, the materials to be added are sand and gravel. These will make it possible to obtain a better distributed particle size curve. However, to avoid the presence of clay clods, it is necessary to ensure that the mixing of these materials is done optimally. Ash can also be used as a stabilizer for soils that are too clayey. It increases the resistance to compression, and therefore decreases the shrinkage and thus the swelling. Ash has no effect on water resistance. Since Sara's quarry sample is well graded and already naturally contains $7.67 \%$ gravel, stabilization by mineral addition is not considered necessary.

\section{Stabilization by addition of fibbers}

This is the most widely known and used method in the world. For our project, we opt for rice bran as a stabilizer. It strengthens the soil structure and adapts well to the plastic or viscous state of the soils of the project site. Fibres in general, mainly rice bran, play several important roles [20]. They allow:

- Prevent cracking during drying by distributing the stresses due to the removal of the clay throughout the mass of the material;

- To accelerate the drying by draining the moisture outwards through the channels of the fibres;

- Lighten the material, which improves the insulation properties, as the density of the material is reduced;

- To increase its tensile strength.

Manufacturing and crushing techniques for compressed bricks

Manufacturing of compressed bricks [21,22]

After soil sieving (Figure 6), the proportions of the mixture are presented in Table 3.
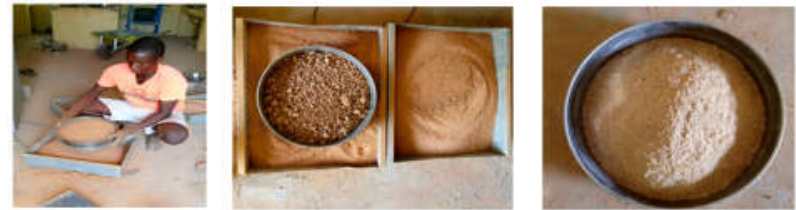

Figure 6: Soil sieve on $5 \mathrm{~mm}$ sieve (left and middle) and rice bran (right)
Table 3: Compressive strength values of compressed bricks

\begin{tabular}{|c|c|c|c|c|}
\hline & 1st test & 2nd test & 3rd test & 4 th test \\
\hline $\begin{array}{l}\text { Earth mass in kg } \\
\text { (for two bricks) }\end{array}$ & 12.59 & 12.59 & 12.59 & 12.59 \\
\hline Mass of rice bran & & & & \\
\hline $\begin{array}{l}\text { (9\% of the earth } \\
\text { mass) in kg }\end{array}$ & 1.13 & 1.13 & 1.13 & 1.13 \\
\hline $\begin{array}{c}\text { Percentage of } \\
\text { water }\end{array}$ & & & & \\
\hline $\begin{array}{c}\text { Volume of water } \\
\text { in litres }\end{array}$ & $16 \%$ & $18 \%$ & $22 \%$ & $24 \%$ \\
\hline Percentage of & & & & \\
\hline $\begin{array}{c}\text { Volume of water } \\
\text { in litres }\end{array}$ & 2.01 & 2.27 & 2.77 & 3.02 \\
\hline $\begin{array}{l}\text { Wet mass in kg } \\
\text { of a compressed } \\
\text { brick }\end{array}$ & 6.36 & 6.00 & 7.80 & 8.30 \\
\hline Drying time & \multicolumn{4}{|c|}{28 days away from the sun } \\
\hline Dry mass in kg & 5,70 & 5,23 & 6,59 & 6.72 \\
\hline $\begin{array}{c}\text { Moisture } \\
\text { content in \% }\end{array}$ & 11,50 & 14,73 & 18,37 & 23,61 \\
\hline $\begin{array}{l}\text { Average crush } \\
\text { force in } \mathrm{KN}\end{array}$ & 5.00 & 5.00 & 25.00 & 17,50 \\
\hline $\begin{array}{l}\text { Brick surface in } \\
\mathrm{cm}^{2}\end{array}$ & 206.25 & 155.25 & 210.00 & 202.50 \\
\hline $\begin{array}{c}\text { Resistance to } \\
\text { compression in } \\
\mathrm{kN} / \mathrm{cm}^{2}\end{array}$ & 0.0242 & 0.0322 & 0.1190 & 0.0864 \\
\hline $\begin{array}{c}\text { Resistance to } \\
\text { compression in } \\
\mathrm{kg} / \mathrm{cm}^{2}\end{array}$ & 2.42 & 3.22 & 11.90 & 8.64 \\
\hline
\end{tabular}

\section{Brick crushing test}

The methods of mechanical characterization of BTC (Compressed Earth Bricks) aim to determine the behaviour of the brick in its future use. According to Cédric FLAMENT, 2003, unlike traditional blocks, no French standard indicates the method of characterization of BTC. Several crushing methods are allowed for this purpose. We use the technique of testing $1 / 2$ block of brick made with a mechanical press with a compressive force ranging from 5 $\mathrm{kN}$ to $10 \mathrm{kN}$ (Figure 7) to crush the compressed bricks with a Controlab hydraulic concrete press (Figure 8).
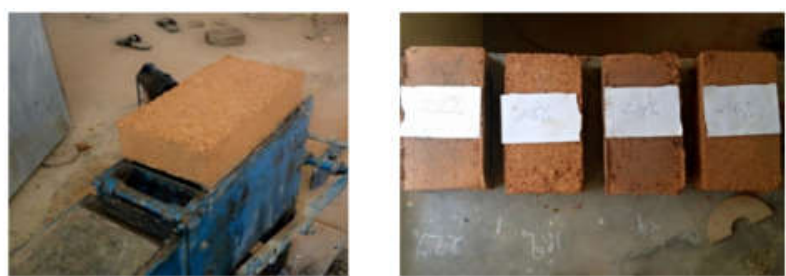

Figure 7: Making bricks with a press (left) and a cure (right)

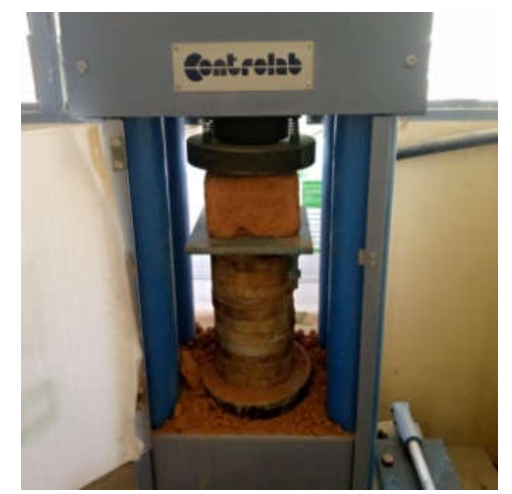

Figure 8: Crushing test of a compressed brick 


\section{Results and Discussion}

After determining, analyzing and interpreting the test results (Table 4) on the samples from the four quarries in and around Pala, it is concluded that those of Sara's quarry are suitable for earthen constructions and can therefore, used to produce compressed bricks. These are red-grained soils consisting of silty soil with the following characteristics:

- Water content by weight $\mathrm{W}_{\text {Pond. }}=0.75 \%$ (Table 5);

- Coefficient of uniformity $\mathrm{Cu}_{\mathrm{u}}=14.40$ and Coefficient of curvature $\mathrm{C}_{\mathrm{c}}=1.37$ : It is a well-graded soil that presages good compaction (Table 6);

- Plasticity index IP=13.86: Little plastic soil, therefore little sensitive to bad weather (humidity and dryness). Less cracking and volumetric variations should be observed on compressed bricks. (Table 7)

Table 4: Analysis and Interpretation of Field Identification Test Results

\begin{tabular}{|c|c|c|c|c|}
\hline $\begin{array}{l}\text { Samples } \\
\text { Careers } \\
\text { from: }\end{array}$ & $\begin{array}{l}\text { Visual } \\
\text { Touch }\end{array}$ & Test Hand Wash & $\begin{array}{l}\text { Test Hand } \\
\text { Wash }\end{array}$ & Cigar Test \\
\hline $\begin{array}{l}\text { Goub- } \\
\text { Goub }\end{array}$ & $\begin{array}{l}\text { Brown } \\
\text { grainy } \\
\text { soil }\end{array}$ & $\begin{array}{l}\text { Sensation of low } \\
\text { roughness; after } \\
\text { humidification, } \\
\text { the soil has } \\
\text { become } \\
\text { moderately } \\
\text { plastic, silty, } \\
\text { sandy loam. }\end{array}$ & $\begin{array}{l}\text { Hands not } \\
\text { too } \\
\text { difficult to } \\
\text { wash, } \\
\text { sensation } \\
\text { of } \\
\text { powdery } \\
\text { soil: silty } \\
\text { soil. }\end{array}$ & $\begin{array}{l}\text { The fallen tip } \\
\text { measures } 12 \\
\mathrm{~cm} \text { : it is a soil } \\
\text { adapted to } \\
\text { earthen } \\
\text { constructions. }\end{array}$ \\
\hline Madagascar & $\begin{array}{l}\text { White- } \\
\text { orange } \\
\text { garnet } \\
\text { soil }\end{array}$ & $\begin{array}{l}\text { Sensation of a } \\
\text { slight roughness; } \\
\text { after } \\
\text { humidification, } \\
\text { the soil has } \\
\text { become } \\
\text { moderately } \\
\text { plastic, the soil is } \\
\text { silky: sandy silt. }\end{array}$ & $\begin{array}{l}\text { Hands not } \\
\text { too } \\
\text { difficult to } \\
\text { wash, } \\
\text { sensation } \\
\text { of a: } \\
\text { powder } \\
\text { ground. }\end{array}$ & $\begin{array}{l}\text { The fallen tip } \\
\text { measures } 10 \\
\mathrm{~cm} \text { : it is a soil } \\
\text { suitable for } \\
\text { earthen } \\
\text { constructions. }\end{array}$ \\
\hline Yatilim & $\begin{array}{l}\text { Greyish } \\
\text { grainy } \\
\text { soil }\end{array}$ & $\begin{array}{l}\text { Rough sensation, } \\
\text { no cohesion } \\
\text { between grains: } \\
\text { sandy soil. }\end{array}$ & $\begin{array}{l}\text { The soil is } \\
\text { easily } \\
\text { rinsed, so } \\
\text { it is sandy } \\
\text { soil: not } \\
\text { good for } \\
\text { building. }\end{array}$ & $\begin{array}{l}\text { The first } \\
\text { fallen tip } \\
\text { measures less } \\
\text { than } 5 \mathrm{~cm} \text {. } \\
\text { This is a } \\
\text { sandy earth: } \\
\text { Soil not } \\
\text { adapted to } \\
\text { earthen } \\
\text { constructions } \\
\text { because the } \\
\text { collar was } \\
\text { divided into } \\
\text { three pieces }\end{array}$ \\
\hline Sara & $\begin{array}{l}\text { Red } \\
\text { grainy } \\
\text { soil }\end{array}$ & $\begin{array}{l}\text { Sensation of low } \\
\text { roughness and } \\
\text { after } \\
\text { humidification, } \\
\text { the sample } \\
\text { became medium } \\
\text { plastic, the earth } \\
\text { is silty. }\end{array}$ & $\begin{array}{l}\text { Hands not } \\
\text { too } \\
\text { difficult to } \\
\text { wash, } \\
\text { sensation } \\
\text { of } \\
\text { powdery } \\
\text { soil: silty } \\
\text { soil. }\end{array}$ & $\begin{array}{l}\text { The fallen tip } \\
\text { measures } 6 \\
\mathrm{~cm} \text { : it is a soil } \\
\text { suitable for } \\
\text { earthen } \\
\text { constructions. }\end{array}$ \\
\hline
\end{tabular}

- Consistency Index IC $=2.68$ : Soil of hard consistency which means that this soil is difficult to scratch with the thumbnail. (Table 7)

Table 5: Water content values w in $\%$

\begin{tabular}{|c|c|c|c|}
\hline $\begin{array}{l}\text { Samples } \\
\text { Career of: }\end{array}$ & Wet Mass (g) & Dry mass (g) & $\begin{array}{c}w \\
(\%)\end{array}$ \\
\hline Goub-goub & 200,20 & 198,50 & 0.86 \\
\hline Madagascar & 200,00 & 199,28 & 1.65 \\
\hline Yatilim & 200,00 & 147,06 & 0.36 \\
\hline Sara & 220,00 & 218,36 & 0.75 \\
\hline
\end{tabular}

Table 6: Values of Uniformity $\mathrm{C}_{\mathrm{u}}$ and Curvature $\mathrm{C}_{\mathrm{c}}$

\begin{tabular}{|c|c|c|c|c|}
\hline $\begin{array}{l}\text { Samples } \\
\text { Career of: }\end{array}$ & Nature & $\mathrm{C}_{\mathrm{u}}$ & $\mathrm{C}_{\mathrm{c}}$ & $\begin{array}{c}\text { Analysis } \\
\text { and interpretation }\end{array}$ \\
\hline Goub-goub & Coarse sand & 3.46 & 0.82 & Poorly graded soil \\
\hline Madagascar & $\begin{array}{l}\text { Coarse matrix } \\
\text { soil }\end{array}$ & 3.20 & 1.15 & Poorly graded soil \\
\hline Yatilim & Medium sand & 3.57 & 0.96 & Poorly graded soil \\
\hline Sara & $\begin{array}{c}\text { Fine sand } \\
\text { mixture } \\
\text { and low average }\end{array}$ & 14.40 & 1.37 & Well graded soil \\
\hline
\end{tabular}

Samples from the other three quarries (Goub-goub, Madacascar and Yatilim) require changes, especially in grain size (texture) by adding grains of missing dimensions or by reducing grains of excess dimensions in order to bring them back to a well graded and little plastic state. This is the case of the Yatilim sample which consists of sandy soil; this makes it impossible to manufacture the rolls for determining its plasticity limit. Also, a change in the structure by adding mineral, vegetable or animal binders may be necessary if abundant cracking, removal or swelling is observed on compressed bricks during the dry cure.

Results of crushing tests on compressed brick

The optimum moisture content corresponding to the maximum compressive strength $\mathrm{R}_{\mathrm{Cmax}}=11.80 \mathrm{MPa}$ of the compressed bricks is determined from Figure 9 and is equal to $\mathrm{W}_{\text {opt. }}=18.40 \%$. The actual water content $\mathrm{W}_{\text {réelle }}$ is equal to the difference between the optimal water content $\mathrm{W}_{\text {opt. }}$ and the water content $\mathrm{W}_{\text {pond.: }} \mathrm{W}_{\text {réelle }}=\mathrm{W}_{\text {opt. }}-\mathrm{W}_{\text {pond. }}=$ $18.40-0.75=17.65 \%$.

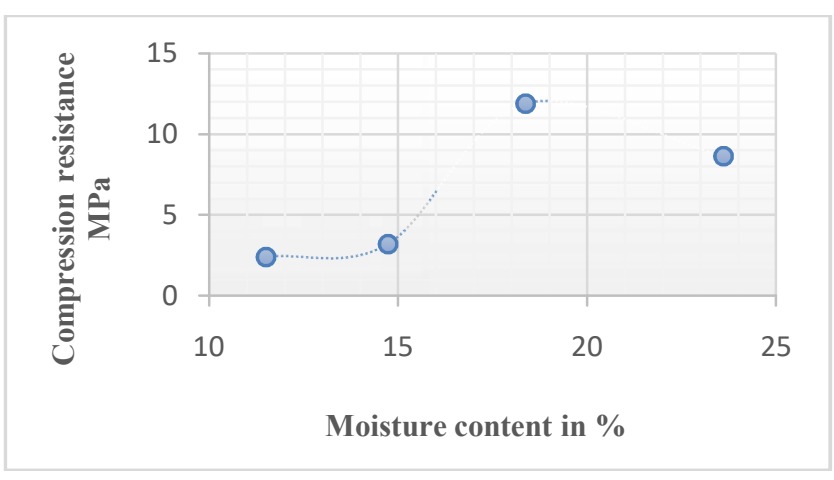

Figure 9: Curve of compressive strength as a function of water content

After treatment of 7 days, we find that before crushing, the compressed bricks present some cracking and withdrawals which deform them especially on the edges. In the analysis of the stabilization techniques mentioned in sub-paragraph 2.2.3, we have considered that simple compression stabilization, although the selected soil is suitable, is not sufficient to produce perfect bricks. This is why we have associated with stabilization by simple compression, stabilization by addition of fibres; rice bran at $9 \%$ of the mass of the soil sample, although it requires a significant amount of water $(18.40 \%)$ to be able to bind it to the solid grains of the chosen earth. Indeed, a small amount of water makes the brick fragile even if it is well compressed. Therefore, it took eight (08) days for a brick to dry properly. Also, during the drying time, the rice bran decomposes giving the brick a brown colour tinged with black (Figure 10). Observing a cut of the rice-pressed brick 
in Figure 10, this combination of two stabilizing techniques seems appropriate as we observe the absence of cracking and the geometric shape of the bricks are constant.

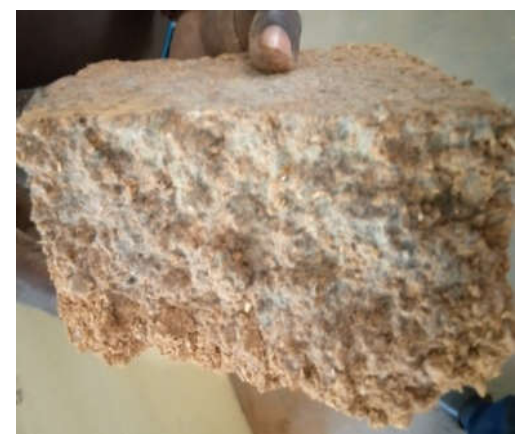

Figure 10: Section of a brick stabilized by the sound of rice

\section{Conclusions}

The region of Mayo-Kebbi West in Chad has within it building materials of acceptable geotechnical and mechanical characteristics. In fact, of the samples collected from four sites in and around Pala, those from Sara's quarry are considered good and suitable. They are then used to make bricks stabilized by compression to the sound of rice using a brick press. In view of the results of the mechanical tests on these bricks, it emerges that they are beautiful and well adapted to earthen constructions because, we obtain a resistance to compression of 11.80 $\mathrm{MPa}$, value between $5 \mathrm{MPa}$ and $20 \mathrm{MPa}$; an interval recommended by Doat et al. (1979). Also, these results are promoters because they comply with the requirements of the International Center for Earth Construction, CRAterre [23]. In addition, there is no cracking or dimensional variation of the bricks manufactured. However, to be able to link rice bran to the solid grains of the earth, this stabilization requires a significant amount of water $(18.40 \%)$. In short, this study, which integrates the results of investigations both in the quarries and in the laboratory, reveals that a soil consisting of silky earth, well graded, little plastic and of hard consistency is suitable for producing compressed earth bricks. Finally, contrary to the ideas that the earth is a fragile material reserved for the poor, the earth can present a good resistance and stability like concrete provided it is studied and well analyzed.

\section{Acknowledgments}

We sincerely thank the Director General of ENSTP, Pr Koïna Rodoumta for the funding; Mr Koïvoudou Locatus and $\mathrm{Mr}$ Keukouareu Banda for their contribution on the ground and in the laboratory.

\section{References}

1. Karka, B. R., et al. 2019, Land Habitat Construction Model: Case of Adobe Manual in South Africa Sahara. Int. J. Innovation Appl. Stud. (IJIAS), 883-7.

2. Yves, C. 2010, Properties and Characteristics of Building Materials. Betting (FR). Monitor 2010, 2nd Ed.

3. Amzina Sadick Djala, Production of compressed earth blocks treated with natural substances and characterization of water properties. Master's thesis in civil engineering, 2IE, class of 2010-2011

4. Claire-Anne de Chazelle, Land Construction Principle. Archaeogages42 April-July 2015.

5. Fact-finding Mission, Study Report on Mining and Petroleum Resources in Mayo-Kebbi West. February 2013.
6. Flament, C. Refinement of Granular Washing Fines: Application to Raw Earth Construction. PhD thesis, 2003, p. 227.

7. Anger \& Fontaine, "Overlapping Earth Layers by Horizons. 2009: P. 100-101.

8. Renonet Karka BOZABE, Bruno BASSA, Adoum WAIBAYE and koïna RODOUMTA, Measurement of compressibility parameters for the evaluation of the degree of settlement and the consolidation time of saturated clay soils. Africa SCIENCE 13(4) (2017) P. 66 - 80.

9. Bruno Bassa, Renonet Karka Bozabe and Adoum Issak, 2021. "Main engineering properties of stabilized earth block bricks formulated with soils from N'djamena - Chad". Int. J. Adv. Res. (IJAR) 9 (05), 1132-11140.

10. Renonet Karka BOZABE, Bruno BASSA, Adoum WAIBAYE and koïna RODOUMTA, Measurement of shear strength parameters for the assessment of load-bearing capacity of saturated clay soils. Revue du CAMES - Sciences Appliquées et de l'Ingénieur 2017 - Vol. 2(1), pp. 22-28.

11. Imoh Christopher, A. et al., 2021, Understanding the Effect of Compaction Energies on the Strength Indices and Durability of Oyster Shell Ash-Lateritic Soil Mixtures for Use in Road Works. Eng. Appl. Sci. Res. (EASR) 48 (2): 151-60.

12. Bozabe Renonet Karka and Bassa Bruno, 2021, Experimental study of the behavior of clay blocks stabilized with lime by simple compression for the construction of walls. Journal of Materials and Engineering (JMSE-B) 11 (4-6) 64-75. David Publishing Company (DPC)

13. Jehanne Paulus, Study of an earthen construction. Master's thesis in Civil Engineering and Architect, University of Liège - Faculty of Applied Sciences, 2014-2015.

14. BS 1377. 1990, Methods of Testing Soil for Civil Engineering Purposes. London: British Standards Institution.

15. BS 1924. 1990, Methods of Testing for Stabilized Soil. London: British Standards Institution.

16. American Society for Testing and Materials (ASTM). 1992, Annual Book of Standards Volume 04.08. Philadelphia.

17. Ingles, O. G., and Metcalf, J. B. 1972, Soil Stabilization Principles and Practice. Sydney: Butterworths.

18. H. Houben, H. Guillaud, 1995, Treaty on Earth Construction. parenthesis edition, Marseille, France, $355 \mathrm{P}$.

19. Hubert Guillaud et al., 1995, Compressed earth blocks, Volume II. Design and Construction Manual., $151 \mathrm{p}$.

20. Ali Abakar, Abdallah Dadi Mahamat, Andre Donnot, JeanLouis Tanguier and Riad Benelmir, Physical and Chemical Characteristics of Rice Straw. Res. J. App. Sci. Eng. Technol. (RJASET), 17(4): 115-121, 2020.

21. Olivier, M., and Mesbah, A. 1997, Earth Construction Mechanics, Procedure for Conducting Resistance Tests on Compressed Earth Blocks. Bull. Lab Liaison.

22. Olivier, and Mesbah, A., The Earth Material: Static Compaction Test for Compressed Earth Bricks. 1986, Bull. Lab Liaison.

23. CRAterre. 1985, Building in Earth. Alternative ed., Paris. 286 P. 